\title{
A Rare Lymphatico-Venous Communication Associated with Duplication of Thoracic Duct
}

\author{
Una rara Comunicación Linfático-venosa Asociada \\ con Duplicación del Conducto Torácico
}

"Anu Vinod Ranade; "Rajalakshmi Rai; "Latha Venkatraya Prabhu \& **Mangala Kumaran

\begin{abstract}
ANU, V. R.; RAJALAKSHMI, R.; LATHA, V. P. \& MANGALA, K. A rare lymphatico-venous communication associated with duplication of thoracic duct. Int. J. Morphol., 24(2):155-158, 2006.

SUMMARY: An unusual presentation of the duplication of thoracic duct with a rare lymphatico- venous communication was found during the routine dissection for undergraduate students. The thoracic duct duplicated at the level of T12 vertebra. Normally thoracic duct opens into the junction of left internal jugular vein and subclavian vein. On the right side of the neck, the right lymphatic duct conveys the lymph from the head and neck, the upper extremity and the right side of the thorax to the right innominate vein. Here, the duplicated thoracic duct on the left side opened directly into the inferior vena cava. The above case is discussed with regard to its development, incidence, and clinical significance.
\end{abstract}

KEY WORDS: Thoracic duct; Inferior vena cava; Lymphatico-venous communications; Cisterna chyli; Lymphatic duct.

\section{INTRODUCTION}

The lymphatic system is a network of channels that are found in all tissues in organs throughout the body. These channels, except for the lacteals which contain a milky fluid called chyle, contain a clear liquid known as lymph which drains to the lymph nodes and ultimately reaches the thoracic duct or the right lymphatic duct which direct the lymph into the venous system at the junction of the jugular and subclavian veins on either side (Leeds, 1997).

The thoracic duct begins from the upper end of cisterna chyli at the lower border of T12 vertebra and enters the thorax usually through the aortic opening of the diaphragm (Dutta, 2000). It passes upwards in the posterior mediastinum behind the oesaphagus. Opposite T5 vertebra the thoracic duct inclines to the left and then runs upwards in the superior mediastinum, along the left edge of the oesaphagus. At the root of the neck, it arches laterally opposite the transverse process of $\mathrm{C} 7$ vertebra and finally turns downwards to terminate in the angle formed by the junction of the left internal jugular vein and the left subclavian vein (Dutta).

\section{CASE REPORT}

During dissection of abdomen for undergraduate students for the past 3 years about 25 cadavers of both sexes have been observed for any variations in the thoracic duct. In one cadaver, we observed an unusual variation in the origin, course, and its drainage into the venous system.

In the present case, the thoracic duct was seen as a Y shaped bifurcation. The two limbs of the bifurcation were connected with an elongated sac like dilatation on either side (Fig. 1). The cisterna chyli, which usually continues as thoracic duct, was not present in this case. The dilatation measured about $18.5 \mathrm{~cm}$ on the right side and $12.5 \mathrm{~cm}$ on the left side. These were seen as extending from T11 vertebra to L4 vertebra (Fig. 2). At the level of T12 vertebra, the two limbs of the bifurcation united to form a single trunk, which continues as thoracic duct. Just below the union, a small duct interconnected the two limbs with each other. The length of the right limb was shorter $(8.5 \mathrm{~cm})$ and that of the left limb was longer $(12.5 \mathrm{~cm})$. One of the notable variations was the communication between the left sac like dilatation and the inferior vena cava. Two

\footnotetext{
* Department of Anatomy, Kasturba Medical College, Mangalore, Karnataka, 575004, India.

** Department of Anatomy, Father Muller's Medical College, Mangalore, Karnataka, 575002, India.
} 
small ducts, measuring about $3.5 \mathrm{~cm}$ and $2.5 \mathrm{~cm}$ were seen arising from the caudal end of the left dilatation, which united to form a single duct (length $2 \mathrm{~cm}$ ) and opened into

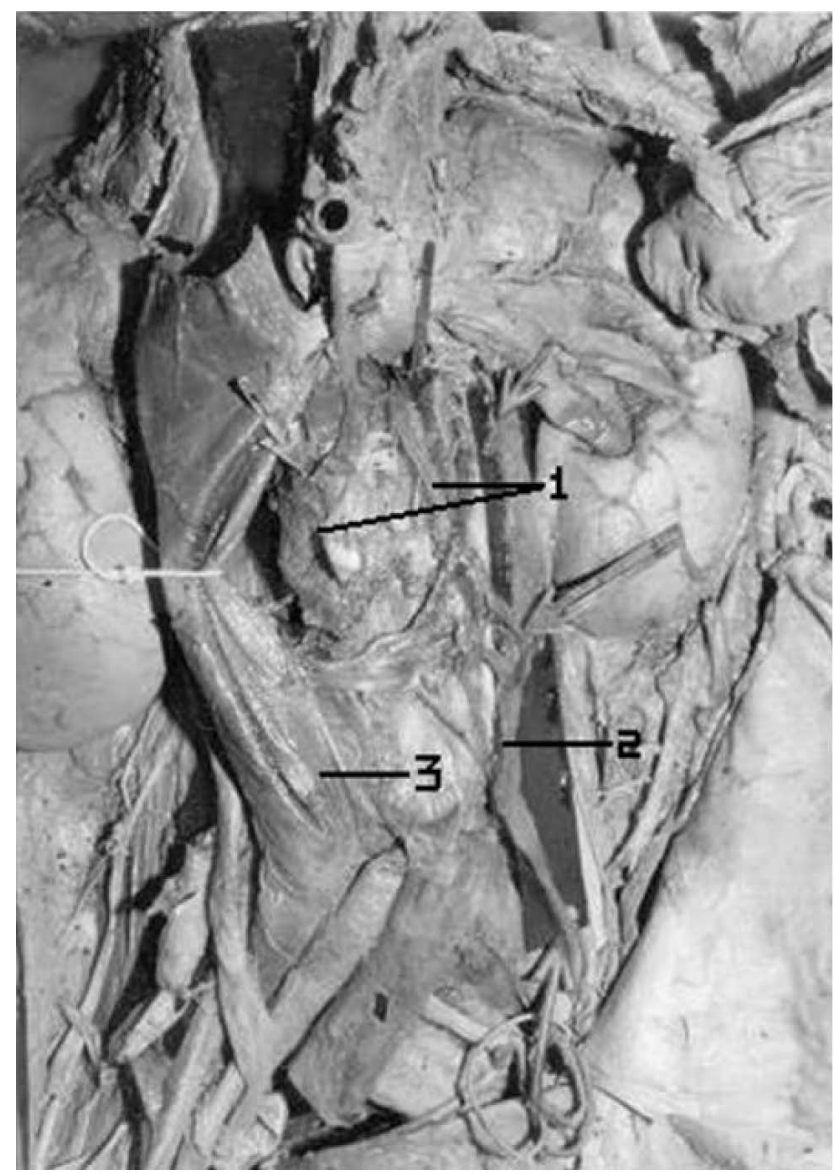

Fig. 1. 1. Duplicated thoracic duct; 2. Left sac; 3. Inferior vena cava.

\section{DISCUSSION}

Lymphatico-venous communications have been reported from time to time ever since Eustachius discovered the thoracic duct tap in 1563 (Job, 1918). In rats, lymphatico-venous communications have been found with the inferior vena cava and portal vein (Job). In certain South American monkeys, the lymphatic vessels from the abdominal viscera and the lower limbs open constantly into the renal veins or into the inferior vena cava (Silvester, 1912).

Two major theories exist on the embryological origin of lymphatic system. The centrifugal or venous budding theory and the centripetal theory. The centrifugal theory states that the lymphatic endothelium develops from the venous endothelium. The centripetal theory states that the inferior vena cava at the level of lower border of L3 vertebra. This small duct passed posterior to the descending aorta.

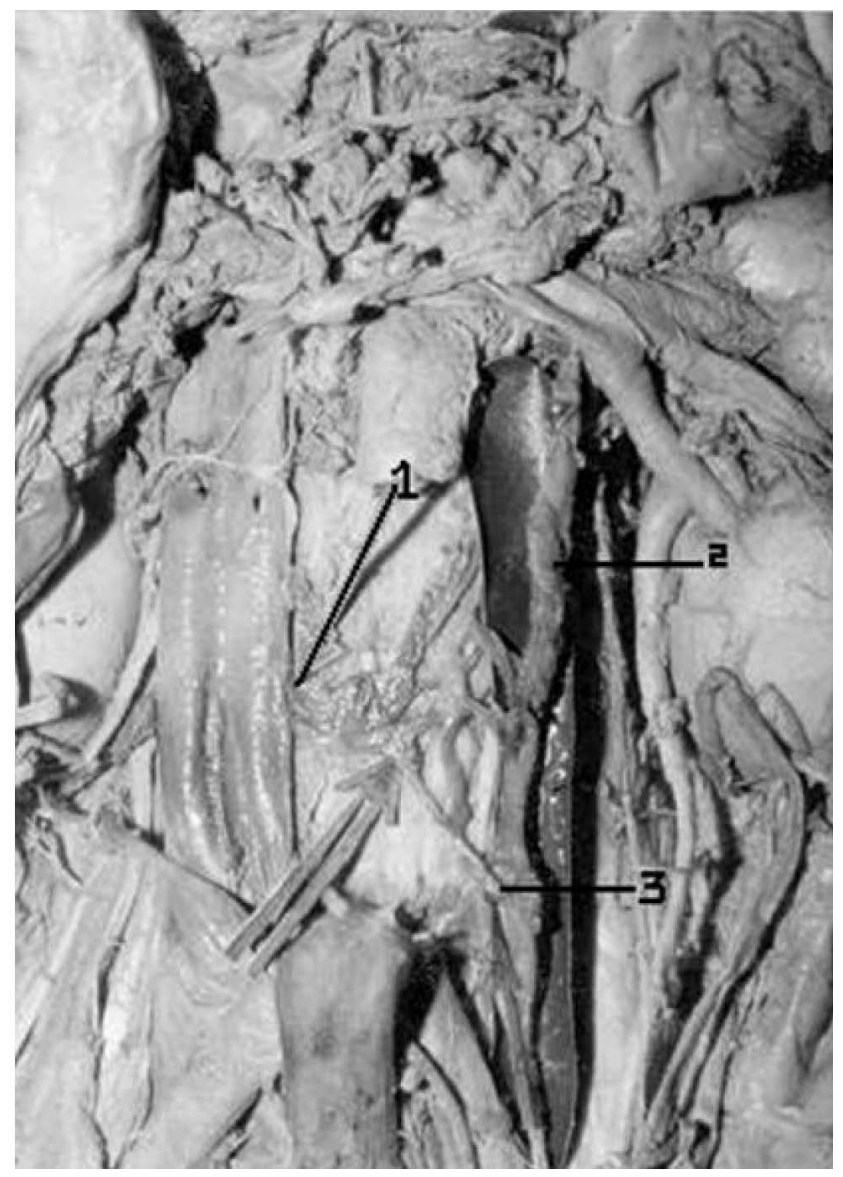

Fig. 2. 1. Communication with the inferior vena cava; 2. Left sac; 3. Communication with the left sac. both systems, venous and lymphatic, develop from undifferentiated mesenchymal cells (Lasinski, 1988). During development some variation may occur, in particular in the area where the lower extensions of the thoracic duct meet the lumbar lymphatic plexus. On an embryological basis, in the pre-vertebral region additional lymphatico-venous communication might be expected. But the possible lymphatico-venous communication elsewhere in the body always point to developmental aberrations or to pathology (Van der Putti \& Van limborgh, 1980).

The opening of the thoracic duct into the inferior vena cava is unusual and rare. A few reports exist on variations of thoracic duct and its duplications. Anson \& Chester (1971), reported that thoracic duct begins at the 
level of the 1 st or $2^{\text {nd }}$ lumbar vertebra in the form of an elongated dilatation, that represents an idealized pattern from which there are numerous and surgically significant departures. In many instances, the level of convergence of the contributory channels is thoracic and not the lumbar (Anson \& Chester). Often two multiple sacculations are present in the course of two or three converging channels. Cross anastomosis frequently occurs giving the complex, the appearance of a plexus, rather than that of a simple duct. In some cases, a median vessel of uniformly small calibre ascends from abdomen through the thorax in un-interrupted course (Anson \& Chester).

Rusznayak et al. (1967), reported that lymph produced in normal circumstances is much more than the amount which drains out via the lymphatic channels. They also concluded that there were no lymphatico-venous anastomoses other than in the neck in normal circumstances. According to Jossifow (1905), the cisterna chyli may be largely dilated lumbar trunk or an anastomotic network or may be a derivative of the lumbar trunk, which pierces the right crus of the diaphragm. However, both the manner and the level of formation of the thoracic duct vary considerably. He stated that, the point of union of the two lumbar trunks might vary from the level of the second lumbar to that of the $11^{\text {th }}$ thoracic vertebra. He found cisterna in only 50 to $60 \%$ of his cases and Davis (1915) found 1 in only $50 \%$ of the 22 bodies he investigated. Since the development of the thoracic duct is basically a complex process, the etiology that results in the formation of this case is uncertain. However, this could be due to the fact that pre-vertebral main lymphatics develop from a number of separate primordia all derived from venous walls (Van der Putti and Van Limborgh, 1980).

Therefore the connection between the thoracic duct and the inferior vena cava may be due to the persistent earlier venous sprouts. Probably such connections may be there between the inferior vena cava and the primitive thoracic duct. In normal conditions no such lymphaticovenous communication exist other than in the neck. However, through a thorough understanding of the anatomy of the lymphatic system, researchers and clinicians can develop the appropriate models and most efficient means of treatment for different populations of patients who may develop lymphoedema.

ANU,V. R.; RAJALAKSHMI, R.; LATHA,V. P. \& MANGALA,K. Una rara comunicación linfático-venosa asociada con duplicación del conducto torácico. Int. J. Morphol., 24(2):155-158, 2006.

RESUMEN: Una inusual presentación de duplicación del conducto torácico con una rara comunicación linfático-venosa, fue encontrada durante una disección de rutina, por estudiantes de pregrado. El conducto torácico se encuentra duplicado a nivel de la vértebra T12. Normalmente el conducto torácico se abre en la unión de la venas yugular interna izquierda y subclavia izquierda. En el lado derecho del cuello, el conducto linfático derecho recibe la linfa de la parte derecha de la cabeza y del cuello, del miembro superior derecho y lado derecho del tórax. El conducto torácico duplicado en el lado izquierdo se abrió directamente en la vena cava inferior. Este caso es discutido con respecto a su desarrollo, incidencia y significación clínica.

PALABRAS CLAVE: Conducto torácico; Vena cava inferior; Comunicaciones linfático-venosas; Cisterna del quilo; Conducto linfático.

\section{REFERENCES}

Anson, B. J. \& Chester, B. Mc Vay. Surgical anatomy. $5^{\text {th }}$ Ed. W. B. Saunders Company, Philadelphia, 1971. pp.442-6.

Davis, H. K. A statically study of the thoracic duct in man. Am. J. Anat., 17:211-44, 1915.

Dutta, A. K. Essentials of human anatomy. In: Thorax and Abdomen. $5^{\text {th }}$ Ed. Current Books International, 2000. pp.105-6.
Job, T. T. Lymphatico-venous communication in Rats and their significance. Am. J. Anat., 24:467-91, 1918.

Jossifow, G. M. Der Afang des Duct thoracicus and desen Erweiferung. Arch. Anat Physiol. Wissen Med., 68-76, 1905.

Lasinski, B. The lymphatic system in pathology: Implications for the physical therapist. Allen A., Ed. Saunders, Philadelphia, 1998. pp. 477-507. 
Leeds, S. E. Three centuries of history of lymphatic system. Surgery, Gynecology and Obstetrics, 104:105-6, 1977.

Rusznayak, I.; Mihaly, Foldi. \& Szabo, G. Lymphatics and lymph circulation: Physiology and pathology. Purgamon Press, New York, 1967.

Van der Putti, S. C.\& Van Limborgh, J. The embryonic development of the lymphatic system in man. Acta. Morphol. Neerl. Scand., 18: 323-35, 1980.

Silvester, C. F. On the presence of permanent communications between the lymphatics and the venous system at the level of the renal veins in adult South American Monkeys. Am. J. Anat., 12:447-71, 1912.
Correspondence to:

Dr. Anu V. Ranade

Department of Anatomy

CBS, KMC, Bejai,

Mangalore

Karnataka 575004

India

Mobile №: 9886117221

Email:anuranade@yahoo.co.in

Received: 19-10-2005

Accepted: 20-01-2006 